\title{
A Study on Cultivation and Yield Performance of Oyster Mushroom (Pleurotus ostreatus) on Wheat Straw Mixed with Horticultural Waste (Apple Pomace) in Different Ratio and their Nutritional Evaluation
}

\author{
Shruti Pathania ${ }^{1 *}$, Nivedita Sharma ${ }^{1}$ and Dharmesh Gupta ${ }^{2}$ \\ ${ }^{1}$ Microbiology Research Laboratory, Department of Basic Sciences, ${ }^{2}$ Mycology, Department of \\ Plant Pathology, Dr. Y.S. Parmar University of Horticulture and Forestry, \\ Nauni, Solan, H.P., India \\ *Corresponding author
}

\section{A B S T R A C T}

Keywords

Pleurotus

ostreatus, Apple

pomace, Wheat

straw, Biological

efficiency.

Article Info

Accepted:

23 June 2017

Available Online:

10 August 2017
Waste of certain process can be the input source of other sectors in order to reduce environmental pollution. The research experiment was carried out to investigate the cultivation of oyster mushroom on horticultural waste i.e. apple pomace and wheat straw mixed in the different ratio. It was found that the best yield of mushroom was observed when $0.50 \mathrm{~kg}$ of apple pomace mixed with $1.50 \mathrm{~kg}$ of apple pomace maximum fruiting body i.e. 28 were observed with approximate weight of $110 \mathrm{gm}$ with highest biological efficiency of $54.23 \%$ which is higher than the yield obtained from wheat straw recommending it blending with wheat straw. There was a significant increase in yield of mushroom in apple pomace + straw as compared to control i.e. wheat straw. The NPK found to be $3 \%, 0.18 \%$, $2.6 \%$ respectively and $3.20 \%$ of fat content.

\section{Introduction}

Agriculture sector occupies a key position in the Indian economy. It provides employment to about $65 \%$ of the working population of India. Around one-quarter of India's national income originates from the agriculture sector. The global food and nutritional security of growing population is a great challenge, which looks for new crop as a source of food and nutrition. In this context, mushrooms find a favor which can be grown even by landless people, that too on waste material and could be a source for proteineous food (Ambili and Nitiya 2014). Use of mushrooms as food and neutraceutical have been known since time immemorial, as it is evident from the description in old epics Vedas and Bible. Earlier civilization had also valued mushrooms for delicacy and therapeutic value.

The mushroom cultivation has grown up in almost all the parts of the world and during last decades, the world mushroom production achieved the growth rate of about $10 \%$. In India, owing to varied agro-climate and abundance of farm waste, different types of 
temperate, tropical and sub-tropical mushrooms are cultivated throughout the country (Shah et al., 2004).

Pleurotus ostreatus (white-rot fungi), also known as oyster mushroom, is commercially important in the world mushroom market. Mushrooms are one kind of edible fungi belonging to the genus Pleurotus under the class Basidiomycetes. Oyster mushroom is an edible mushroom having excellent flavor and taste. $P$. ostreatus has received increasing attention for applications in bio-bleaching and the catalysis of difficult chemical conversions in the paper industry, textile dye decolorization, and detoxification of environmental pollutants (Park et al., 2014). Mushrooms are prized for their exclusive flavor and deliciousness, they are rich in proteins, contain less fat, less carbohydrates and salt and rich in fibres and have high vitamin B12 and folic acid which are uncommon in vegetables. High availability of lysine and tryptophan and other amino acids usually absent in cereals make them ideal for food for patients suffering from hypertension, diabetes and obesity (Carel et al., 2013). Mushrooms require carbon, nitrogen and inorganic compounds as their nutritional sources and the main nutrients are carbon sources such as cellulose, hemicellulose and lignin and recommending the use of various wastes for growth of P.ostreatus.

The waste obtained from fruit processing industry is extremely diverse due to the use of wide variety of fruits and vegetables, the broad range of processes and the multiplicity of the product. Full utilization of horticultural produce is a requirement and a demand that needs to be met by countries wishing to implement low-waste technology in their agribusiness. Food processing industries generate high amount of waste and direct disposal of such residues poses a serious threat to the environment and represents an important loss of biomass (Vendruscolo et al.,
2007). Apple pomace is the main by-product of food processing industry of Himachal Pradesh resulting from pressing apples for juice or cider and it accounts for 25-35\% of the dry mass of apple. Apple pomaces are easy to obtain are not hardwood or softwood material (harsh and expensive pretreatment methods are not necessary) and have considerably high fermentable sugar content.

It is a waste and its disposal is an environmental problem but a previous resources, its utilization is challenging and opportunities to technologies. Apple pomace is an important fruit industrial waste that remain unutilized and creating an environmental pollution. Therefore it can be utilized along with the wheat straw as a substrate for P.ostreatus production. Several million tones of AP are generated because of its high carbohydrate content it's used for microbial processes for single cell protein, enzymes, mushroom product ethanol, low alcoholic drinks and pigments (Bhushan et al., 2008). Therefore this horticultural waste can be utilized and replaced with wheat straw for mushroom cultivation under mushroom house.

Hence, in this study, we attempt to identify the alternative substrates i.e. apple pomace and wheat straw residue and to assess the growth performance and yield as well as the nutrient content of $P$. ostreatus.

\section{Materials and Methods}

The research project was conducted in the mushroom house, Department of Mycology, Dr Y S Parmar University of Horticulture and Forestry, Nauni, Solan during the February to April year 2002.

\section{Sterilization}

Sterilization is the process which is involved in killing of micro-organisms. Sterilization 
requires a minimum of $121^{\circ} \mathrm{C}$ steam at $15 \mathrm{Psi}$ (1 atm pressure) for 15-20 minutes.

\section{Preparation of the mother culture}

The fresh culture of mushroom i.e. Pleurotus ostreatus was collected from Department of Mycology, Chambaghat, Himachal Pradesh, India. Sub-culturing of the mushroom was done on PDA with rose Bengal dye. The agar plate is then entirely covered tightly with the help of the wrapper. The culture plate is then incubated in the incubator at $25-27^{\circ} \mathrm{C}$ for $7-14$ days. After the incubation period, fungus had grown on the entire agar plate.

\section{Preparation of spawn bags}

Wheat grain was commonly used for making spawn as it shows very good mycelium growth, wheat grains were thoroughly washed and soaked for 24 hours in water, and then sieved. After overnight soaking, $10 \mathrm{~kg}$ of grain is taken in a vessel with $15 \mathrm{~L}$ of water. It is boiled for about 15 minutes and allowed to cool for 15 minutes, water is drained and the spawn is dried in cotton cloth. $120 \mathrm{~g}$ of gypsum $\left(\mathrm{CaSO}_{4} \cdot 2 \mathrm{H}_{2} \mathrm{O}\right)$ is added with $30 \mathrm{~g}$ of ground limestone $\left(\mathrm{CaCO}_{3}\right)$ and mixed well. The grain was packed into the polypropylene bags. One bag contains 300-350g of the prepared grain and is packed tightly. The packed bags are then autoclaved at $121 \mathrm{C}$.

\section{Preparation of mushroom bed}

The materials used and methods applied as 2 $\mathrm{kg}$ of Wheat straw; Apple pomace $0.25 \mathrm{~kg}$ $+1.75 \mathrm{~kg}$ Wheat straw; Apple pomace $0.50+$ $1.50 \mathrm{Kg}$ Wheat straw; Apple pomace $0.75 \mathrm{~kg}$ $+1.25 \mathrm{~kg}$ Wheat straw and Apple pomace $1 \mathrm{~kg}+1 \mathrm{Kg}$ Wheat straw.

The substrates were soaked in water for 24 hours to moisten them thoroughly and were stalked in the autoclaved distilled water on cemented floor so as to remove the excessive moisture from the substrates to get $65-75 \%$ moisture level. The substrates were fermented for 5 days by covering with polythene sheet before filling the bags. Each of five treatments bags were autoclaved at $121^{\circ} \mathrm{C}$ at 15-20 lbs pressure and allowed to cool. After sterilization next day the bags were inoculated with the spawn of Oyster mushroom (Pleurotus ostreatus) at the Spawn running: It is evident from table 1 that spawn rate of 5\% per bag according to the dry weight of substrates. The bags were than inoculated for spawn running under complete darkness at controlled temperature of $25^{\circ} \mathrm{C}$. Mushroom cultivation has two important phases viz, spawn running and fructification.

The temperature was controlled by electric heaters at $25^{\circ} \mathrm{C}$ for spawn running and 17 $20^{\circ} \mathrm{C}$ for fruiting body formation. The humidity of bags was accomplished by spraying of water on them twice a day. Oxygen is essential for mushroom during fructification. For this purpose exhaust fans were used for the exhaust of gases from mushroom growing room. The pinholes were also made in the bags with the help of paper pins for exhaust of gases. The bags were watered three times in a day during cropping

\section{Biological efficiency}

Biological efficiency of mushrooms were calculated by dividing weight of fresh mushroom yield (in $\mathrm{Kg}$ ) by weight of air dried substrate (in $\mathrm{Kg}$ ) and multiply by 100 (Banik and Nandi 2004).

$\begin{aligned} & \text { Biological efficiency } \\ & \frac{\text { Yield of fresh mushroom in gm }}{\text { Total weight of dry sustrate used }(\mathrm{gm})}\end{aligned} \times 100$

Experiment was repeated thrice. The data was pooled and ANOVA was used to test the significance of biological efficiency of mushroom. 


\section{Chemical toxicity test of mushroom}

A drop of juice was pressed out of the fresh fruit body on a piece of newspaper. After the spot had dried, hydrochloric acid was dropped on it. A blue spot indicated the presence of toxic.

\section{Estimation of $N, P$ and $K$ in the biomass of substrate}

When pasteurization was completed, samples of the substrates and supplements were analyzed for percent organic carbon, $\mathrm{pH}$, nitrogen and fat as indicators of substrate quality. Nitrogen\%, Phosphate $\%$ and Potassium $\%$ and fat by ether extract.

Nitrogen content (\%) by micro-Kjeldahl method (Ranganna 1986a)

Total nitrogen in the apple pomace was estimated by Kel Plus Classic Delux model AutoN -analyzer manufactured by Peclican equipment Pvt. Ltd Chennai.

Nitrogen

$(\%)$

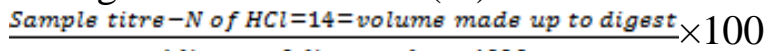

$A$ liquot of digest taken $=1000$

\section{Phosphorus (\%)}

$0.5 \mathrm{~N} \mathrm{NaHCO}_{3}$ at $8.5 \mathrm{pH}$ was used to extract available phosphorus (Olsen's et al., 1954) and determined by spectrophotometrically.

\section{Potassium (\%)}

Potassium was extracted by normal neutral ammonium acetate (Merwin and Peech 1951) and determined on flame photometer

Fats were determined by modified Folch (1957) method

Fat extraction was done by solvent extract using petroleum ether (60-80C) for $16 \mathrm{hrs}$ in a soxlet extraction apparatus. Ether was evaporated. The fats (\%) obtained was estimated as ( $\mathrm{g}$ fat/g dry biomass) $\times 100$.

\section{Data collection and statistical analysis}

The experiment was laid out in Completely Randomized Design (CRD) with five treatments and a control with four replications. Time was recorded in days for the completion of growth of mycelium on substrates, appearance of pinheads and maturation of fruiting bodies in different treatments. The data were also recorded for the yield number of fruiting bodies. The data obtained were statistically analyzed by analysis of variance (Gomez and Gomez 1976).

\section{Results and Discussion}

\section{Anatomical study of Pleurotus ostreatus}

Cross-section of Pleurotus ostreatus lamellae shows no abnormality. Unstained preparation of gills, stalk and pileus mycelium of $P$. ostreatus reveals no absorption of dyes on it. Spores were cylindrical, smooth and hyaline. Four spored, slenderly clavate basidia were found to be attached to irregular, hymenophoral trama and showed normal morphology (Fig. 1a). Lamellae were longdecurrent, crowd, white coloured and having smooth edge when young, later become undulating. Stipe was short and having solid context, longitudinally striate surface, and white in colour. Presence of white coloured spores confirms by spore print (Fig. 1b) and its microscopic view under the image analyzer microscope (Eclipse LV 100 POL polarizing microscope, Nikon) shown in figure 1c.

\section{Spawn running}

It is evident from table 1 that spawn running took 2-3 weeks after inoculation. All 
substrates were inoculated at the same day. Colonization of substrate was completed in 20 days all the bags were opened for primodial formation on the same day (Fig. 2a and b). These results agree with the findings of Tan (1981) who reported that the spawn running took three weeks and fruiting bodies appeared after 2-3 days. Kumari and Achal (2008) stated that colonization of the substrate was completed within 20 days of inoculation.

\section{Pinheads formation}

The pinheads formation is the second stage of mycelial growth during cultivation of mushroom. Small pinheads like structures were observed, these pinheads were formed 67 days after the spawn running. These results are in agreement with Ahmad (1986) who stated that Pleurotus ostreatus completed spawn running in 17-20 days on different substrates and time for pinheads formation was noted as 23-27 days. Pin head formation start after 8 days of spawn run $2 \mathrm{~kg}$ of wheat straw and $0.25 \mathrm{~kg}$ of apple pomace and 1.75 $\mathrm{kg}$ of wheat straw followed by increase in pin head formation as the amount of apple pomace in the ratio increases (Fig. 2c). Shah et al., (2004) reported that primordial formation of $P$. ostreatus appears 27-34 days of inoculation which is consistent with the results of this study.

\section{Fruiting bodies formation and yield of Oyster mushroom}

This is the third and final stage during the cultivation of mushroom. The fruiting bodies appeared 10 days after pinheads formation (Fig. 3). These findings are in conformity with Quimio (1978) who reported that fruiting bodies 3-4 weeks after inoculation of spawn. The crop of Oyster mushroom was harvested in three flushes. Maximum average yield was estimated from the sawdust. 28 mushroom with average size 110 gm of were obtained from mushroom $0.5 \mathrm{gm}$ of apple pomace and 1.50 wheat straw followed by 18 pieces of mushroom with average weight of $75 \mathrm{gm}$ from $0.25 \mathrm{gm}$ of apple pomace $+1.75 \mathrm{~kg}$ of wheat straw, were as $85 \mathrm{gm}$ of $P$. ostreatus yield with average number of 16 mushroom were observed in control (Fig. 4). The cultivation of Oyster mushroom which is in agreement with the findings of Hami (1990) who studied the Oyster mushroom cultivation on sawdust of different woods and found that Pleurotus ostreatus gave the maximum yield. Kumari and Achal (2008) cultivated $P$. ostreatus on different substrates and reported the highest yield on wheat straw, followed by the combination of paddy and wheat straw. Das and Mukherjee (2007) also found that when weed plants were mixed with rice straw in the ratio $1: 1$, there is increase in the yield than when used individually. Sharma et al., (2013) grows $P$. ostreatus on combination of different substrates such as rice straw, rice straw + wheat straw, rice straw+ paper, sugarcane bagasse and sawdust of alder was investigated with rice straw (control) was found as a best substrate with yield (381.85 gm) and BE (95.46\%).

\section{Chemical toxicity test}

P. ostreatus cultivated on mixed substrate, showed no blue spots on reacting with $\mathrm{HCl}$ on lignin containing paper, revealing the presence of non-toxic compounds. The present study deals with an approach that integrates biotechnology with environmental waste management to achieve zero waste from industries. Cultivated mushrooms were not only found to be normal but also nontoxic.

\section{Biological efficiency}

The biological efficiency was worked out against the dry weight of each substrate. It is clear from table 1 that as a substrate 0.50 
apple pomace +1.50 wheat straw $54.23 \%$ showed best biological efficiency followed $b$ y $40.14 \%$ in $0.25 \mathrm{~kg}$ of apple pomace +1.75 $\mathrm{kg}$ of wheat straw and $20.61 \%$ of biological efficiency in control i.e. $2 \mathrm{~kg}$ of wheat straw.

These results are in line with Hami (1990) who reported that Pleurotus ostreatus gave maximum bioefficiency on sawdust thus recommending it as a substrate for mushroom production. Analysis of the changes in biological efficiency with a switch from wheat straw (control) to the supposedly superior substrates (mixture of apple pomace + wheat straw) indicated that mixture of substrate was superior to wheat straw when cultivating $P$. ostreatus. Apple pomace + wheat straw resulted in the highest biological efficiency increase of $8.0 \%$ compared to control with $5.60 \%$ of efficiency (Table 1 and Figure 5). A number of research reports have been published for biological treatment of kraft pulp and paper industries (Ragunathan and Swaminathan 2004; Singhal et al., 2005). The highest yield (381.85gm) and biological efficiency $(95.46 \%)$ of this mushroom was obtained from rice straw followed by rice straw plus wheat straw, rice straw plus paper and sugarcane bagasse (Sharma et al., 2013).

Wood chips and wheat straw shows highest yield $(780 \mathrm{~g})$ and biological efficiency $(78 \%)$ when combined with wood chips are best substrate for oyster mushroom cultivation (Sofi et al., 2014).

Table.1 Comparison of yield of mushroom, relative humidity (\%) and biological efficiency of $P$. ostreatus on a mixture of apple pomace and wheat straw

\begin{tabular}{|c|c|c|c|c|c|c|c|}
\hline Names of substrate & $\begin{array}{l}\text { Days of } \\
\text { completion } \\
\text { of spawn } \\
\text { running } \\
\text { (Days) }\end{array}$ & $\begin{array}{l}\text { Days of } \\
\text { pinhead } \\
\text { formation } \\
\text { (Days) }\end{array}$ & $\begin{array}{l}\text { Days of } \\
\text { fruiting } \\
\text { body } \\
\text { formation } \\
\text { (Days) }\end{array}$ & $\begin{array}{l}\text { Average number } \\
\text { of fruiting bodies } \\
\text { (Days) }\end{array}$ & $\begin{array}{l}\text { Weight in } \\
\text { (gm) }\end{array}$ & $\begin{array}{l}\text { Relative } \\
\text { humidity } \\
(\%)\end{array}$ & $\begin{array}{l}\text { Biolog } \\
\text { ical } \\
\text { Efficie } \\
\text { ncy } \\
(\%)\end{array}$ \\
\hline $2 \mathrm{~kg}$ of Wheat straw & 20 & 8 & 5 & 16 & $85 \pm 0.54$ & $\begin{array}{l}73.30 \pm \\
0.531\end{array}$ & $\begin{array}{l}5.60 \pm \\
0.091\end{array}$ \\
\hline $\begin{array}{lr}\text { Apple } & \text { pomace } \\
0.25 \mathrm{~kg}+1.75 \quad \mathrm{~kg} \\
\text { Wheat straw }\end{array}$ & 20 & 8 & 5 & 18 & $75 \pm 0.718$ & $\begin{array}{l}90.83 \pm \\
1.23\end{array}$ & $\begin{array}{l}5.50 \pm \\
0.155\end{array}$ \\
\hline $\begin{array}{l}\text { Apple pomace } 0.50 \\
+1.50 \mathrm{Kg}\end{array}$ & 20 & 14 & 5 & 28 & $110 \pm 0.735$ & $\begin{array}{l}89.88 \pm \\
0.817\end{array}$ & $\begin{array}{l}8.80 \pm \\
0.111\end{array}$ \\
\hline $\begin{array}{ll}\text { Apple } & \text { pomace } \\
0.75 \mathrm{~kg} & +1.25 \mathrm{~kg}\end{array}$ & 20 & 15 & 6 & 14 & $40 \pm 0.554$ & $\begin{array}{l}92.35 \pm \\
1.22\end{array}$ & $\begin{array}{l}3.50 \pm \\
0.101\end{array}$ \\
\hline $\begin{array}{l}\text { Wheat straw } \\
\text { Apple pomace } 1 \mathrm{~kg}+\end{array}$ & 20 & 23 & 6 & 12 & $30 \pm 1.109$ & $\begin{array}{l}84.75 \pm \\
0.487\end{array}$ & $\begin{array}{l}3.00 \pm \\
0.427\end{array}$ \\
\hline $\begin{array}{l}\mathrm{CD}_{0.05} \\
\mathrm{SE}\end{array}$ & & & & & $\begin{array}{l}1.395 \\
0.436\end{array}$ & $\begin{array}{l}2.144 \\
0.688\end{array}$ & $\begin{array}{l}0.720 \\
0.231\end{array}$ \\
\hline
\end{tabular}

Table.2 Some chemical constituents of substrates and supplements of the apple pomace and wheat straw

\begin{tabular}{|c|c|c|c|c|}
\hline $\mathrm{P}$ & Nitrogen $(\%)$ & Phosphorus (\%) & Potassium (\%) & Fat content $(\%)$ \\
\hline \multicolumn{5}{|l|}{ Substrate } \\
\hline $\begin{array}{l}\text { Apple pomace }+ \text { Wheat Straw } \\
(0.5 \mathrm{Kg}+1.5 \mathrm{Kg})\end{array}$ & $3 \%$ & 0.18 & 2.6 & 3.20 \\
\hline Wheat Straw & 1.98 & 0.27 & 0.62 & 2.10 \\
\hline
\end{tabular}


Fig.1 a) Morphology of $P$. ostreatus on Cookes red Bengal medium, b) Spore print of fruiting body and c) Microscopic view of $P$. ostreatus under image analyzer microscope

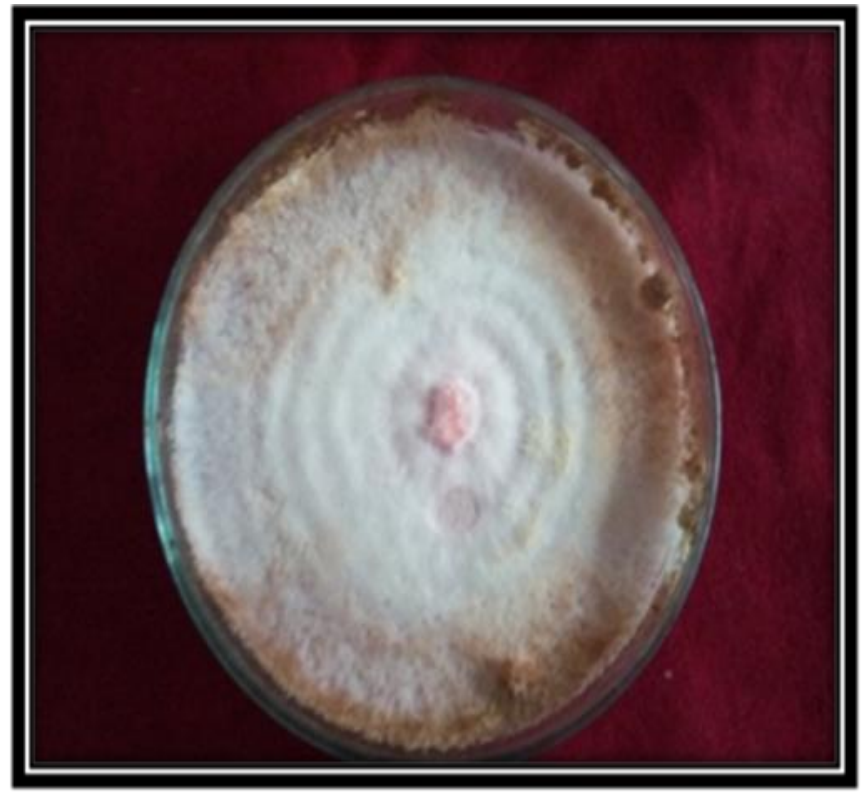

a)P. ostreatus culture on PDA 5 days old (right) and 11 days 0 ld (left).

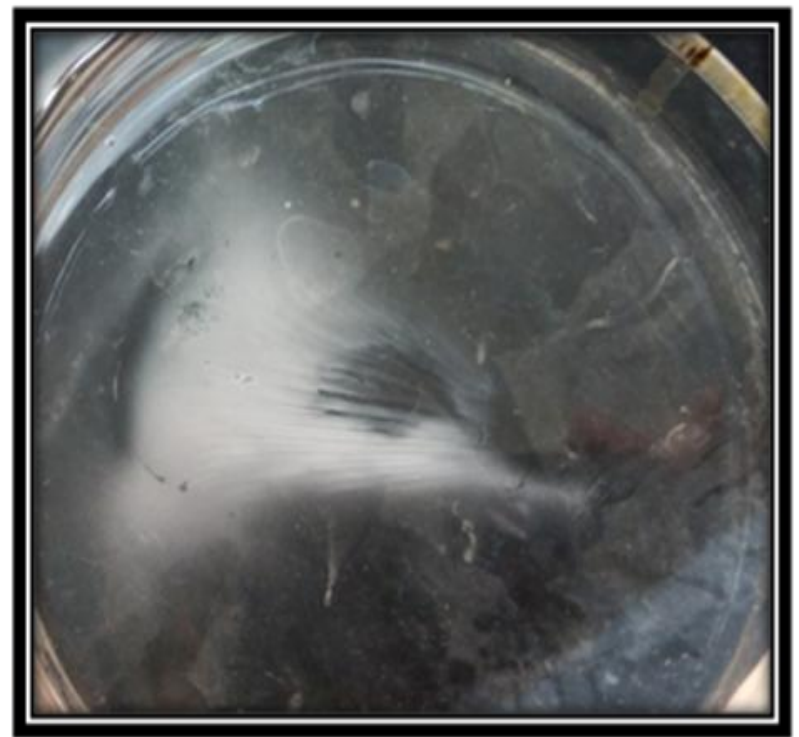

b) Spore print of fruiting body

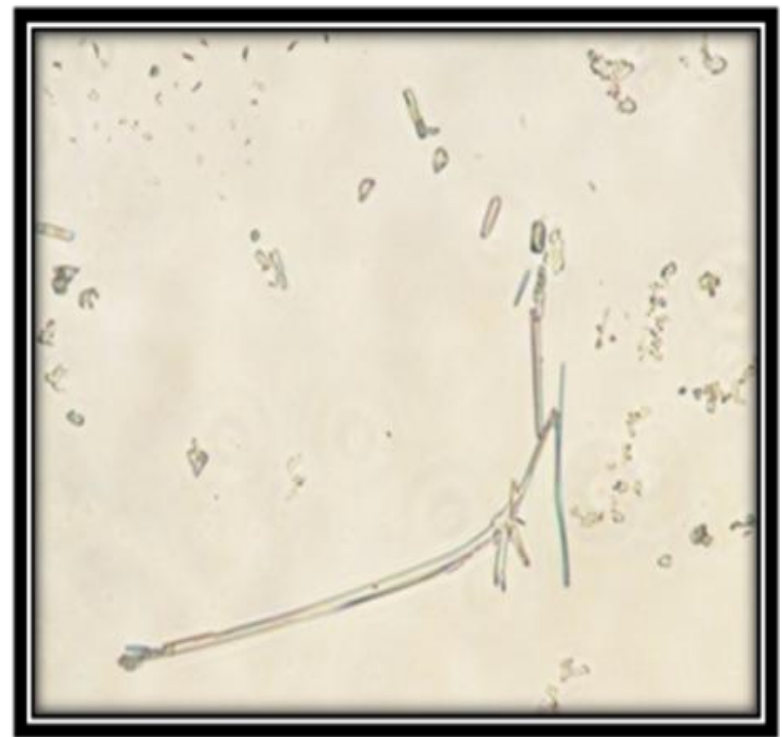

c) Microscopic view of P.ostreatus 
Fig.2 Spawn run of P. ostreatus on mixed substrate (apple + wheat straw)

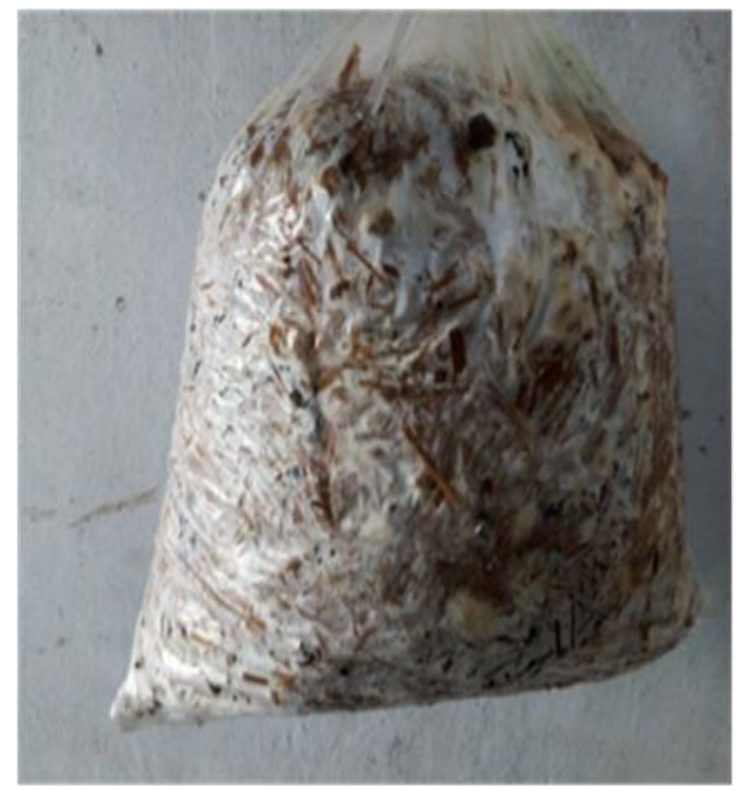

a)Complete spawn run (bag covered with polythene)
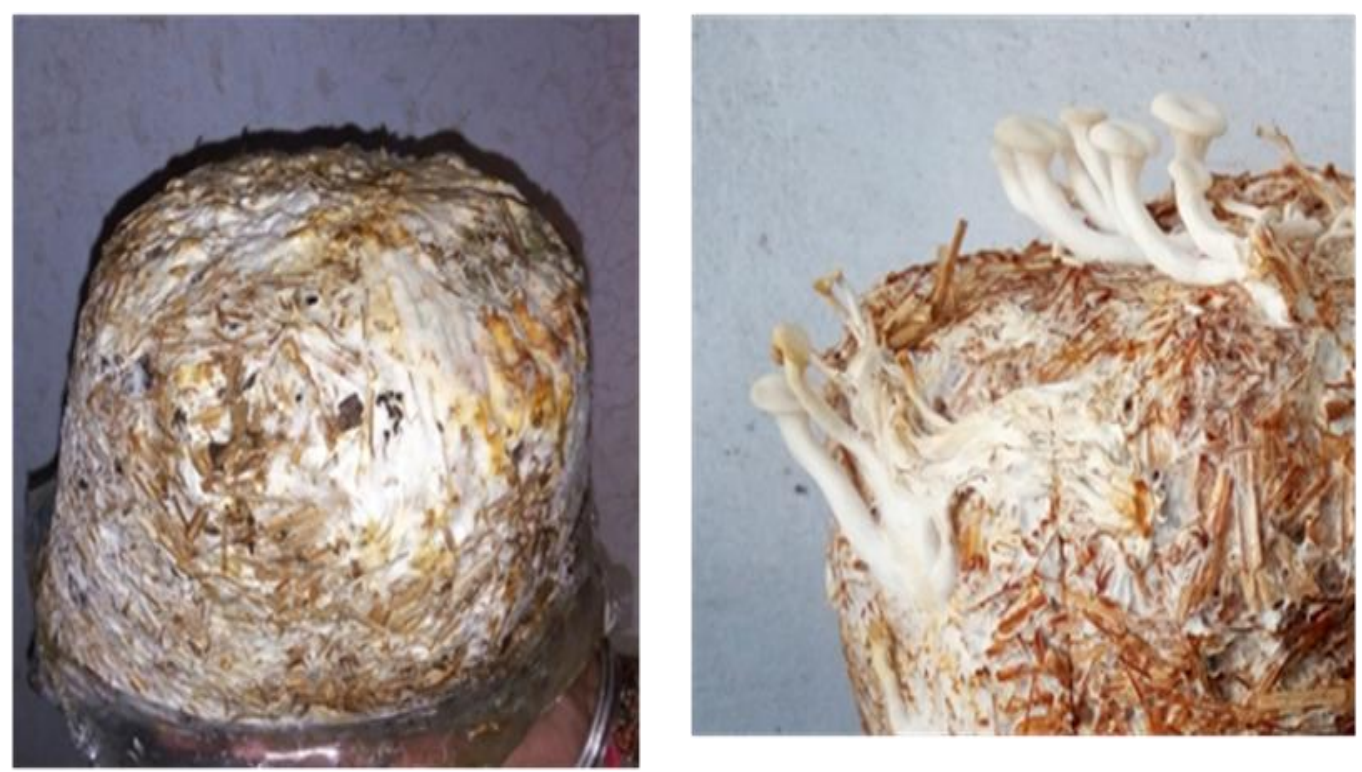

b) Removal of polythene after complete spawn run

c) Mushroom primordia of Pleurotus ostreatus 
Int.J.Curr.Microbiol.App.Sci (2017) 6(8): 2940-2953

Fig.3 The fruiting body of $P$. ostreatus

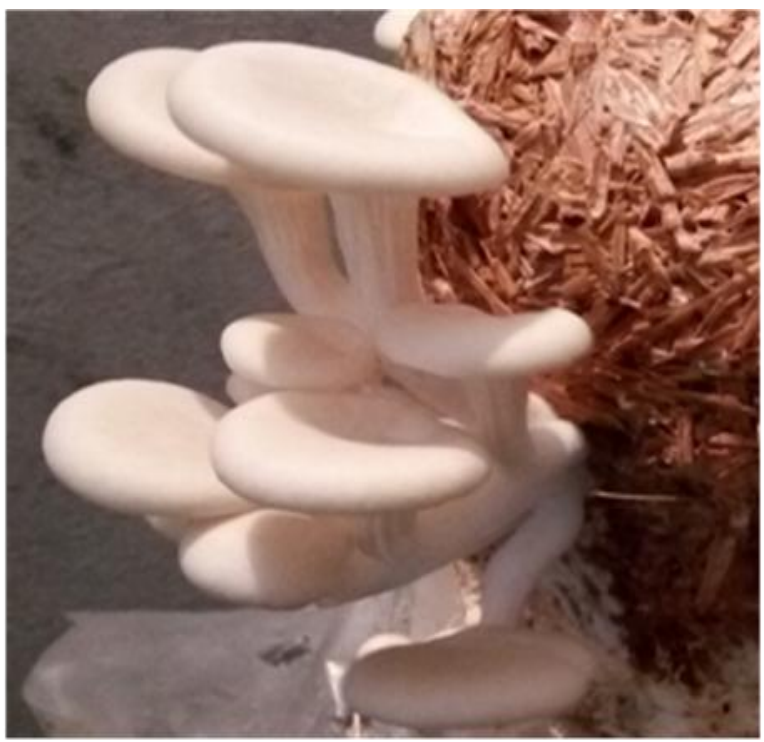

Fruiting body formation
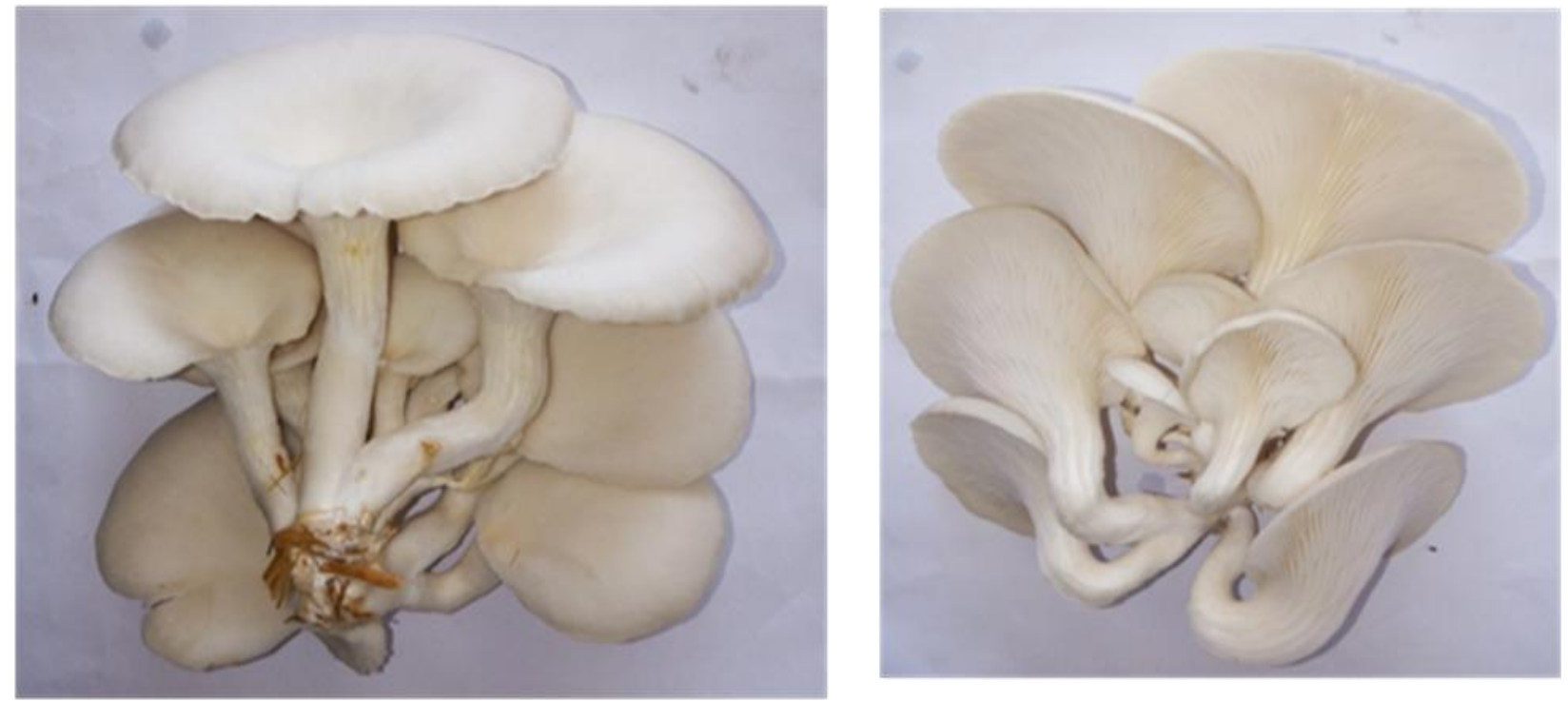

P. Ostreatus after harvesvesting 
Fig.4 The fruiting body formation on wheat straw and apple pomace

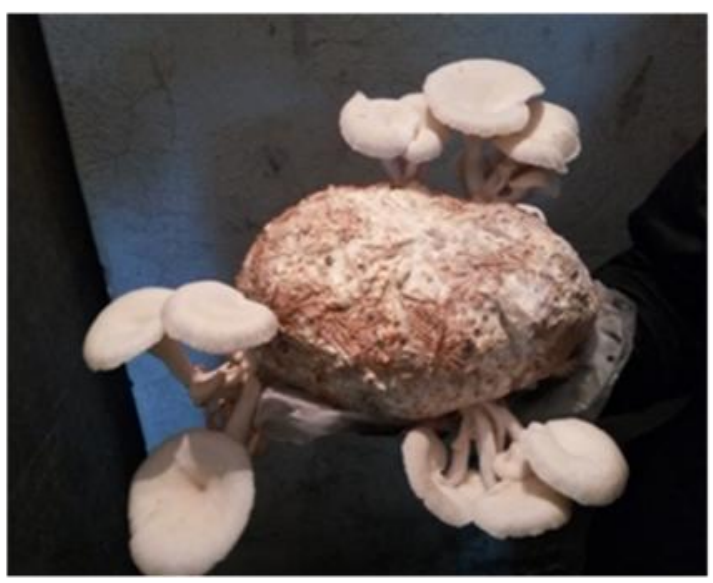

0.25 apple pomace + 1.75 wheat straw

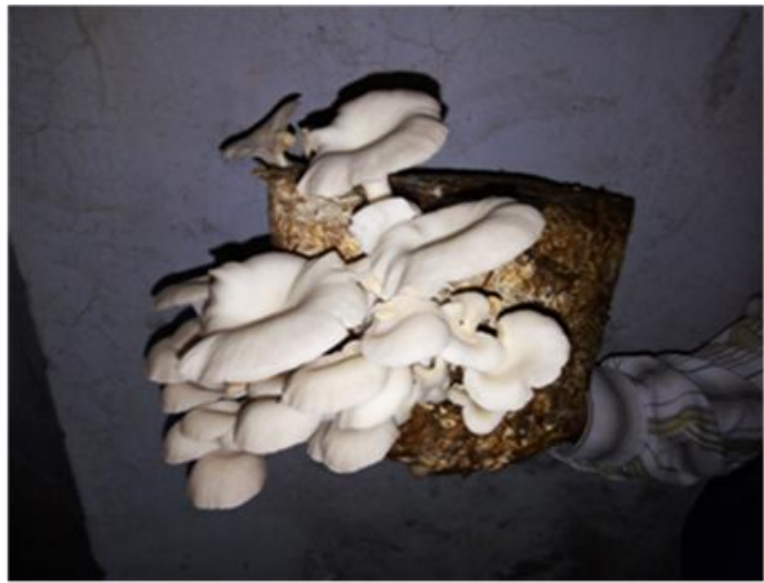

0.50 apple pomace + 1.50 wheat straw

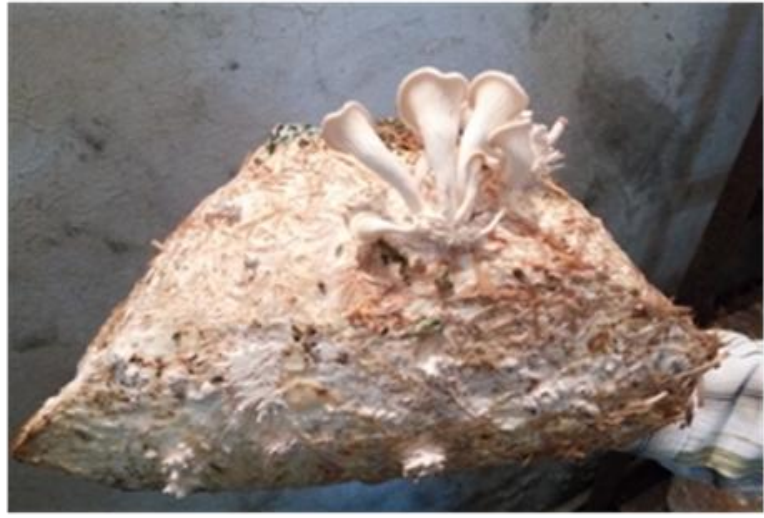

$0.75 \mathrm{~kg}$ apple pomace $+1.25 \mathrm{~kg}$ wheat straw

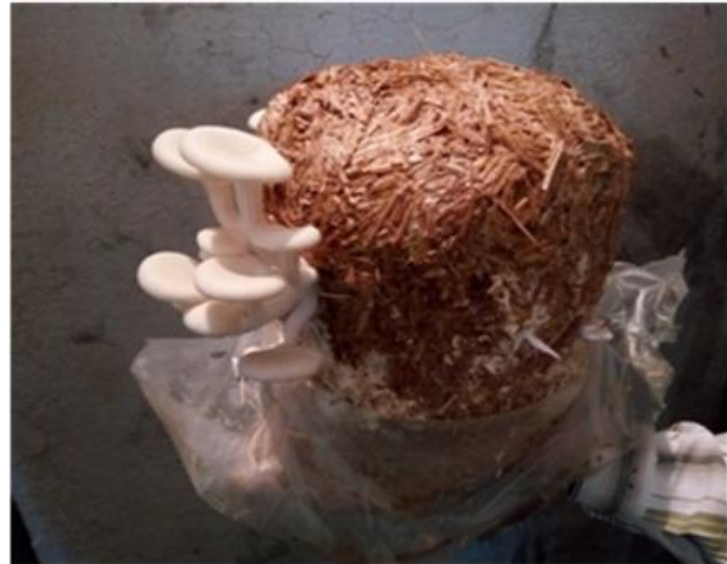

$2 \mathrm{~kg}$ of wheat straw

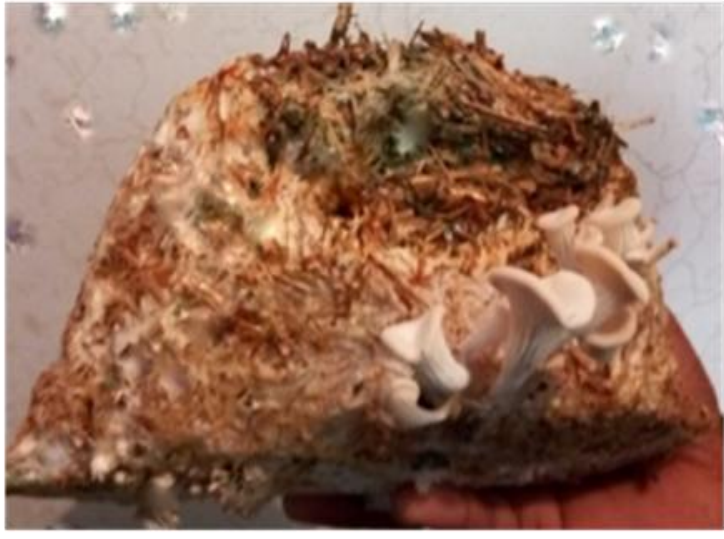

$1 \mathrm{~kg}$ apple pomace $+1 \mathrm{~kg}$ wheat straw 
Fig.5 Yield, relative humidity and Biological efficiency of $P$. ostreatus on biomass

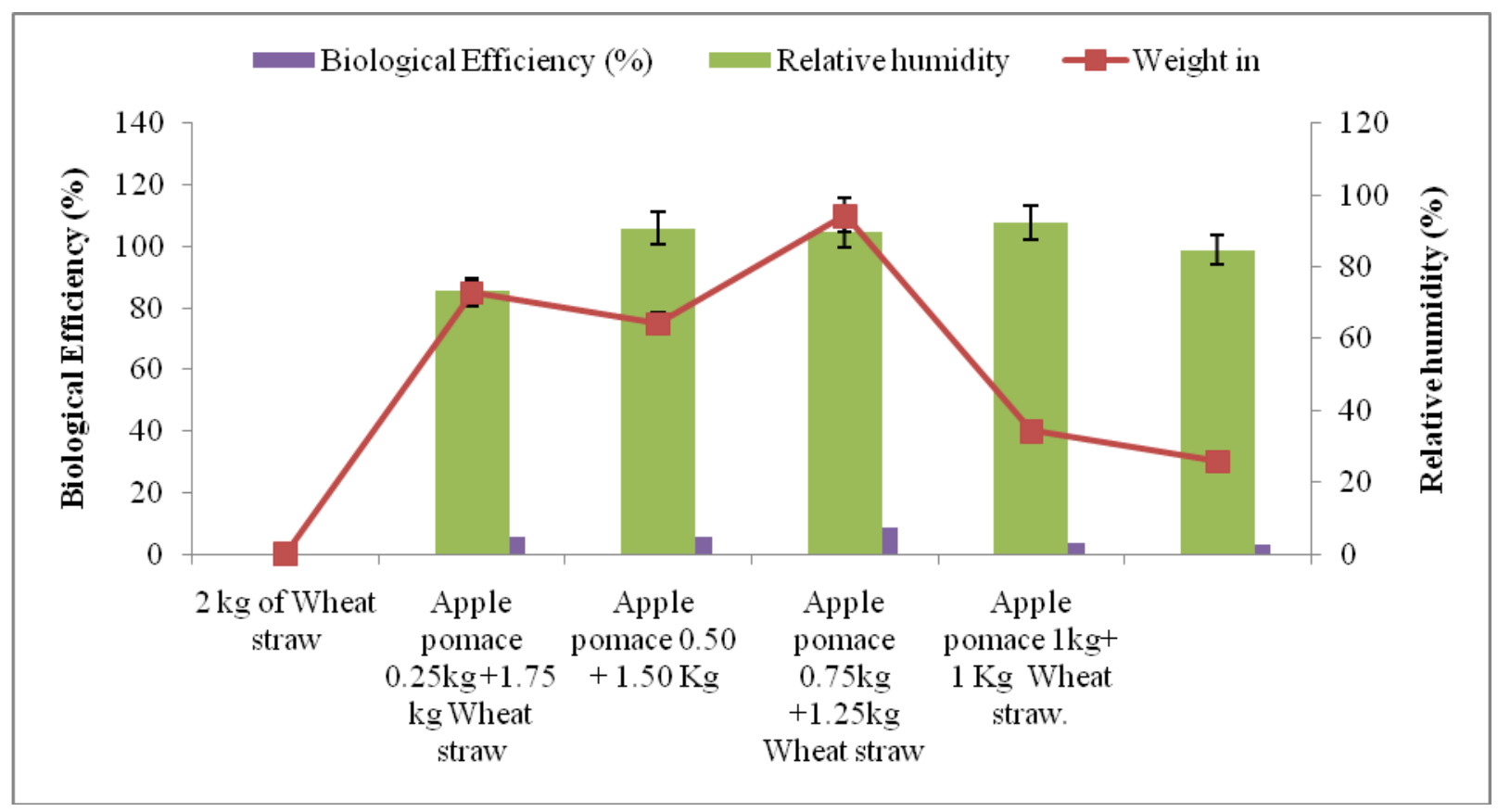

Estimation of N, P and $K$ in the biomass of substrate

Total N, P and K potential of various crop residues i.e. N. P, $\mathrm{K}$ and fat content (Table 2) was estimated from the mixture of apple pomace and wheat straw $(0.5 \mathrm{~kg}+1.5 \mathrm{~kg})$ of biomass and control ( $2 \mathrm{Kg}$ of wheat straw). The NPK and fat content measured to be $3 \%$ nitrogen, $0.18 \%$ of phosphorus, $2.6 \%$ of potassium and $3.20 \%$ of fat content followed by that in control of wheat straw residues with $1.98 \%$ of $\mathrm{N}, 0.27 \%$ of $\mathrm{P}$ and $0.62 \%$ of $\mathrm{P}$ in wheat straw. Therefore it's included that the substrate with growth of P.ostreatus increases the NPK content along with the fat content.

Fanadzo et al., (2009) used the different substrate i.e. wheat straw, maize stover, thatch grass with $25 \%$ increase in biological efficiency of two oyster mushroom species (Pleurotus sajor-caju and P. ostreatus). Park et al., (2014) studied the effect of apple pomace on the growth rate of Pleurotus ostreatus mycelium observed that mycelial growth dramatically increased by $34.5,20$ and
$26 \%$ in solid culture, liquid culture, and solidstate fermentation, respectively, by adding $2.5 \%$ apple pomace. However, the growth of $P$. ostreatus mycelia was slightly inhibited by adding 5 or $10 \%$ compared to $2.5 \%$ apple pomace.

Cultivation of this Mushroom is very simple and low cost production technology, which gives consistent growth with high biological efficiency. Mushroom growing is an ecofriendly activity as it utilizes the waste of environment and in turns produces fruit bodies with excellent and unique nutritional and medicinal attributes. Apple pomace is a waste material, its use in mushroom production should not only be cheaper than grains and the primary products but also contributes to reducing solid waste disposal problems.

The best yield of oyster mushroom obtained by mixing $1.50 \mathrm{~kg}$ of wheat straw and 0.50 of apple pomace with $110 \mathrm{gm}$ of fresh oyster mushroom with $8.80 \%$ of biological efficiency as compared to using wheat straw 
alone. The compositional analysis of apple pomace yielded $36 \%$ of cellulose, $11 \%$ hemicelluloses, $16.60 \%$ of pectin, $8 \%$ of starch and $11 \%$ of lignin. The main function of apple pomace is to provide a reservoir of cellulose, hemicelluloses and lignin which is utilized during the growth and fructification. A decrease in yield of mushroom was lower with increase in the apple pomace/wheat straw mixtures $(0.75 \mathrm{Kg}+1.25 \mathrm{Kg})$ with $40 \%$ yield, $92.35 \%$ biological efficiency and 3.5\% of relative humidity was observed. The study revealed that the yield for mixed substrate i.e. apple pomace and wheat straw was significantly highest yield among all treatments.

Apple pomace has a better decomposition rate they are considered to be a better substrate for growth, mixing of apple pomace with wheat straw yielded the maximum fruiting body and thereby balancing the reservoir of carbon source and energy that is slowly degraded after colonization of substrate completely.

Mycelia growth was very sparse on wheat straw and apple pomace was more dense but grew slowly. Dense, fast growing mycelia were produced on the mixture of substrates (Josephine, 2014). Similar finding was reported by Yang et al., (2014) for using 40$60 \%$ of tea waste along with different waste for production of oyster mushroom.

The lower yield of mushroom in wheat straw may be due the low nitrogen content of the wheat straw as compare to the apple pomace. The addition of protein-rich supplements in the cultivation of mushrooms was an effective method for mushroom cultivation the high nitrogen content of $3.00 \%$ in apple pomace promoting the rapid growth rate of P.ostreatus and low nitrogen $1.98 \%$ in wheat straw leads to less availability of nutrition for the P.ostreatus and thereby leading to lower growth rate.
Different cultivars of Pleurotus has varied composition requirement for the growth of mushroom. These results are consistent with findings by Peksen and Yakupoglu (2009) who reported a positive correlation among yield, $\mathrm{N}$ content of substrate and BE. Substrate composition analysis showed that the proposed supplements (maize bran and cottonseed hull) were superior to the base substrates over both percentage nitrogen and fat. Carbon is readily available from cellulose, hemicellulose and lignin from straw, but nitrogen occurs mainly in a bound form and is not available until it is enzymatically released.

Mushroom cultivation is one of the efficient ways by which residues can be recycled. $P$. ostreatus grown on different substrates are nutritious with high protein, fiber and low fat.

It may also offer economic incentives for agribusiness to examine these residues as valuable resources and develop new enterprises to use them to produce nutritious mushroom products (Ahlawat et al., 2005).

Therefore, the mushroom cultivation may become one of the most profitable agribusiness that could produce food products from different substrates and help to dispose them in an environment friendly manner (Sharma et al., 2013).

\section{Acknowledgements}

The authors are very thankful to the Department of Basic Sciences, Microbiology section for funding this study. We are also like to extend our gratitude to Department of Plant Pathology, UHF, Nauni, Solan were the major part of the experiment were conducted.

\section{Conflict of interest}

The authors have declared that no conflict of interest exists. 


\section{References}

Ahlawat, O.P., Ahlawat, K. and Dhar, B. 2005. Influence of lignocellulolytic enzymes on substrate colonization and yield in monosporous isolates and parent's strains of volvariellavolvacea (bull. fr.) sing. Indian J. Microbiol., 45 (3): 205-210.

Shah, Z.A., Ashraf, M. and Ishtiaq, M. 2004. Comparative study on cultivation and yield performance of oyster mushroom (Pleurotus ostreatus) on different substrates (wheat straw, leaves, saw dust). Pak. J. Nutri., 3 (3): 158-160.

Park, C.H., Lim, J., Lee, Y., Lee, B., Kim, S., Lee, J. and Kim, S. 2007. Optimization and morphology for decolorization of reactive black 5 by Funalia trogii. Enzy. Microb. Technol., 40: 1758- 1764. https://doi.org/10.1016/j.enzmictec.200 6.12 .005

Caral, D.R., Vinay, P., Manasa, P., Kumar, D.V. and Babu, R. 2010. Comparative study of oyster mushroom (pleurotus ostreatus) cultivation by physical and chemical method of sterilization using two different substrates. Mycol., 3: 1217.

Vendruscolo, F., Albuquerque, P.C.M., Streit, F., Esposito, E. and Ninow, J. 2008. Apple pomace: a versatile substrate for biotechnological applications. Crit. Rev. Biotechnol., 28: 1-12. doi: 10.1080/07388550801913840

Bhushan, S., Kalia, K., Sharma, M., Singh, B. and Ahuja, P.S. 2008. Processing of apple pomace for bioactive molecule. Crit. Rev. Biotechnol., 28: 285-296.

Das, S., and Mukherjee, M. 2007. Indoor cultivation of $P$. ostreatus. Philo. Agric., 61: 253-262.

Ranganna, S., 1986. Handbook of analysisand quality control for fruit and vegetable products Tata McGraw-Hill Publishing
Company, New Delhi, India. 1986; pp 124-125.

Olsen, S.R., 1998. The role of rock phosphate solubilizing fungi and vesicular arbuscular mycrorhizze (VAM) into growth of wheat plants fertilized with rock phosphate. World. J. Microbiol. Biotechnol., 14: 211-218. doi:10.1023/A:1008830129262

Merwin, H.D., and Peech, M. 1951. Exchange of soil potassium in the sand slit and clay fractions as influenced by the nature of complementary exchangeable cations. Soil. Sci. American. Proc., 15: 125-128.

Folch, J., Lees, M. and Stanley, G.H.S. 1957. A simple method for the isolation and purification of total lipids from animal tissues. J. Biol. Chem., 226: 497-509.

Gomez, K.A., and Gomez, A.A. 1976. Statistical procedures for agricultural research, $2^{\text {nd }}$ ed. John Willey and Sons, Singapore.

Tan, T.T., 1981. Cotton waste is a fungus (pleurotus) good substrate for cultivation of Pleurotus ostreatus the oyster mushroom. Mushroom Sci., 11: $705-710$.

Kumari, D., and Achal, V. 2008. Effect of different substrates on the production and nonenzymatic antioxidant activity of Pleurotus ostreatus. Life. Sci. J., 5: 73-76.

Ahmad, I., 1986. Some studies on oyster mushroom (Pleurotus spp.) on waste material of corn industry. M.Sc thesis. Department of plant pathology, Faisalabad. p 50

Quimio, T.H., 1978. Cultivation ganoderma the "Pleurotus-way" mushroom. Newsletter Tropics., 6: 12-130.

Hami, H., 1999. Cultivation of oyster mushroom. (Pleurotus spp.) on saw dust of different woods. M.S.c. thesis, department of plant pathology, 
university of agriculture, Faisalabad, Pakistan.

Fanadzo, M., Zireva, D.T., Dube, E. and Mashingaidze, A.B. 2012. Evaluation of various substrates and supplements for biological efficiency of Pleurotus sajorcaju and Pleurotus ostreatus. Afri J Biotechnol., 9 (19): 2756-2761.

Josephine, M. 2014. Solid waste management through mushroom cultivation - an ecofriendly approach. Int. J. Biol. Biomol. Agric. Food Biotechnol.Eng, 8(2): 115117.

Yang, D., Lang, J., Wang, Y., Sun, F., Tao, H., Xu, Q., Zhang, L., Zhang, Z., Ho, Chi-Tang and Wan, X. 2016. Tea waste: an effective and economic substrate for oyster mushroom cultivation. J. Sci. Food Agric., 96: 680-684. doi: 10.1002/jsfa.7140

Ragunathan, R., and Swaminathan, K. 2004. Biological treatment of a pulp and paper industry effluent by Pleurotus spp. World J. Microbiol. Biotechnol., 20: 389-393.
doi:10.1023/B:WIBI.0000033064.6303 $1.1 \mathrm{c}$

Singhal, V., Kumar, A. and Rai, J.P. 2005. Bioremediation of pulp and paper mill effluent with Phanerochaete chrysosporium. J. Environ. Biol., 26: 525-529. PMID: 16334292

Sharma, S., Kailash, P., Yadav, R., Chandra, P. and Pokhrel, P. 2013. Growth and yield of oyster mushroom (Pleurotus ostreatus) on different substrates. $J$. New Biolog. Rep., 2(1): 03-08. doi: 10.1186/s13568-016-0265-1

Sofi, B., Ahmad, M. and Khan, M. 2014. Effect of different grains and alternate substrates on oyster mushroom production. Afr. J. Microbiol. Res., 8(14): 1474-1479.

Peksen, A. and Yakupoglu, G. 2009. Tea waste as a supplement for the cultivation of Ganoderma lucidum. World J. Microbiol. Biotechnol, 25(4): 611-618. DOI: 10.1007/s11274-0089931-z

\section{How to cite this article:}

Shruti Pathania, Nivedita Sharma and Dharmesh Gupta. 2017. A Study on Cultivation and Yield Performance of Oyster Mushroom (Pleurotus ostreatus) on Wheat Straw Mixed with Horticultural Waste (Apple Pomace) in Different Ratio and their Nutritional Evaluation. Int.J.Curr.Microbiol.App.Sci. 6(8): 2940-2953. doi: https://doi.org/10.20546/ijcmas.2017.608.353 